\title{
Nadir Özbek
}

\section{TAŞRAYI YÖNETMEK: SON DÖNEM OSMANLI JANDARMASI (1876-1908)}

$\mathrm{Bu}$ makale Osmanlı jandarmasının tarihine yönelik bir temel oluşturmayı hedeflemektedir. Bu doğrultuda öncelikli olarak birliklerdeki jandarma erleri ve çalışma koşulları üzerinde durulacaktır. Osmanlı bürokratları bu paramiliter polis teşkilatı aracılığıyla merkezi devletin hakimiyetinin sınırlı olduğu vilayetlerde iktidarlarını güçlendirmeyi amaçlamışlardı. Bir çok Avrupa devletinde olduğu gibi Osmanlı İmparatorluğu'nda da onsekizinci yüzyılın sonlarından itibaren devlet egemenliğini tanımlanmış sınırların her noktasında hakim kılmak hayati bir önem taşımaya başlamıştı. Diğer askeri ve sivil kurumlar ve modern idari pratiklerin yanısıra, taşra paramiliter polis teşkilatının oluşturulması Avrupa hükümetlerine merkezi iktidarları güçlendirme ve bu iktidarı daha önce devlet hakimiyetinin sınırlı olduğu bölgelere yayma imkanı sağladı. Dolayısıyla jandarma teşkilatının tarihi hem Avrupa'da hem de Osmanlı İmparatorluğu'nda modern devletin ve modern yönetim tekniklerinin oluşum sürecinin asli unsuru olarak incelenmelidir. Bu çalışma jandarmanın oluşumuna yönelik Avrupa bağlamını gözardı etmemekle birlikte, daha çok söz konusu taşra polis teşkilatının oluşum sürecinin Osmanlı’ya özgü yönleri üzerinde durmaktadır. 